\title{
Analiza TSI pod kątem wymagań wpływających na energochłonność systemu transportu kolejowego
}

\begin{abstract}
W artykule zaprezentowano wyniki analizy Technicznej Specyfikacji Interoperacyjności dla podsystemu Tabor kolejowy - lokomotywy i tabor pasażerski, oraz Techniczna Specyfikacje Interoperacyjności dotyczqca podsystemu „Tabor” transeuropejskiego systemu kolei duzych prędkości pod katem wymagań które moga mieć wptyw na energochtonność transportu kolejowego.
\end{abstract}

\section{Wstęp}

Leżący u podstaw funkcjonowania Unii Europejskiej Traktat Lizboński wskazuje na konieczność dokonywania niezbędnych zmian $\mathrm{w}$ transporcie europejskim w celu ujednolicenia systemu kolei w Europie. Jednoznacznie wskazuje na to cytat: „Aby pomóc osiagnąć cele określone w artykułach 26 i 174 oraz umożliwić obywatelom Unii, podmiotom gospodarczym, wspólnotom regionalnym i lokalnym pełne czerpanie korzyści z ustanowienia obszaru bez granic wewnętrznych, Unia przyczynia się do ustanowienia i rozwoju sieci transeuropejskich $\mathrm{w}$ infrastrukturach transportu, telekomunikacji i energetyki...”. Przywołany art. 26 mówi iż „rynek wewnętrzny obejmuje obszar bez granic wewnętrznych, w którym jest zapewniony swobodny przepływ towarów, osób, usług i kapitału, zgodnie z postanowieniami Traktatów”, a czyni się tak „w celu wspierania harmonijnego rozwoju całej Unii rozwija ona i prowadzi działania służące wzmocnieniu jej spójności gospodarczej, społecznej i terytorialnej"[1].

Unia Europejska stoi przed dużym wyzwaniem, które w ostateczności ma na celu ujednolicenie systemu kolei. Ważnym krokiem w kierunku ujednolicenia kolei Europejskiej była Dyrektywa Rady 96/48/WE z dnia 23 lipca 1996 r. w sprawie interoperacyjności transeuropejskiego systemu kolei dużych prędkości [2]. Kierując się wytycznymi dyrektywy decyzją Komiosji z dnia 21 lutego 2008 r. wprowadzono w życie Techniczną Specyfikację Interoperacyjności dotycząca podsystemu „Tabor" transeuropejskiego systemu kolei dużych prędkości (2008/232/WE) [6]. Kolejna Dyrektywa 2001/16/WE Parlamentu Europejskiego i
Rady Europy z dnia 19 marca 2001 r. dotyczyła interoperacyjności transeuropejskiego systemu kolei konwencjonalnych [3]. Dyrektywy te zostały zastąpione Dyrektywą 2008/57/WE w sprawie interoperacyjności systemu kolei we Wspólnocie (zmienionej Dyrektywa Komisji 2011/18/UE z dnia 1 marca 2011r. zmieniająca załączniki II, V i VI do dyrektywy Parlamentu Europejskiego i Rady 2008/57/WE w sprawie interoperacyjności systemu kolei we wspólnocie[5]) powołującą do życia Techniczną Specyfikację Interoperacyjności (TSI) dla podsystemu tabor kolejowy - tabor pasażerski" systemu kolei konwencjonalnych wprowadzonej Decyzją Komisji z dnia 26 kwietnia 2011 (2011/291/UE) [7].

Celem Technicznych Specyfikacji Interoperacyjności jest postawienie wymagań, który musi spełniać tabor w celu poruszania się po transeuropejskiej sieci kolejowej. Wymagania te maja wpływ na energochłonność transportu kolejowego.

\section{Wymagania TSI dla kolei dużych prędkości}

Jako koleje dużych prędkości należy rozumieć takie, które poruszają się z prędkością powyżej $190 \mathrm{~km} / \mathrm{h}$. TSI wskazuje parametry, które należy uwzględnić projektując poszczególne elementy, a które mogą mieć wpływ na energochłonność.

Pierwszym elementem wymienianym w TSI mogącym mieć wpływ na energochłonność są drzwi zewnętrzne. Wymagania stawiane drzwiom dotyczą sterowania, oraz zasad bezpieczeństwa. Drzwi moga być wyposażone w przyciski do otwierania, który 
musi być podświetlony lub przynajmniej podświetlony na obrzeżu. System drzwi zewnętrznych musi umożliwiać personelowi pociagu (maszyniście lub konduktorowi) zamknięcie i zablokowanie drzwi przed odjazdem pociagu. Dodatkowo, jeśli drzwi zaczną się zamykać musi zostać włączony sygnał dźwiękowy. Drzwi muszą być wyposażone w elementy sygnalizujące awarie, które mogą być zasilane elektrycznie i muszą podlegać kontroli. Elementy te, których kontrola jest wymagana przez TSI, moga być zasilanie elektrycznie i mają bezpośredni wpływ na energochłonność. Drugim aspektem dotyczącym drzwi jest ich ilość i wielkość. Ilość i wielkość drzwi uwarunkowana jest sytuacjami awaryjnymi i musi umożliwić opuszczenie pojazdu w ciagu trzech minut. Parametry te wpływają bezpośrednio na energochłonność podczas normalnej eksploatacji. Otwieranie i zamykanie drzwi, czas ich pozostawania $\mathrm{w}$ stanie otwartym ma bezpośredni wpływ na warunki środowiskowe panujące wewnątrz pojazdu a $\mathrm{w}$ związku $\mathrm{z}$ tym pośredni wpływ na energochłonność. Ponieważ pasażerom należy zapewnić odpowiednie warunki podróżowania (temperatura, wilgotność, wentylacja, itp.) zasilane elektrycznie urządzenia odpowiedzialne za komfort pasażerów przyczyniają się do zwiększenia energochłonności pojazdu.

Kolejnym elementem omówionym w TSI mającym wpływ na energochłonność są szyby kabiny maszynisty. Wymaganiem koniecznym do spełnienia jest obowiązek zastosowania szyb ogrzewanych wyprodukowanych ze szkła bezpiecznego. Szyby powinny być również wyposażone $\mathrm{w}$ urządzenia odladzające, odmgławiające oraz zewnętrzne urządzenia czyszczące. Elektryczne urządzenia zapewniające spełnienie stawianych wymagań w sposób bezpośredni wpływaja na pobór i zużycie energii.

Istotnymi wymaganiami stawianymi pojazdom mającymi wpływ na pobór energii są wytyczne dotyczące procesu hamowania. Według wytycznych TSI pociągi powinny być wyposażone w systemy kontroli hamowania $\mathrm{z}$ jednym lub kilkoma poziomami opdźndiảnła. elektrycznych hamulców dynamicznych uwzględnia się w obliczaniu skuteczności tylko wtedy, gdy:

- ich działanie jest niezależne od obecności napięcia w sieci trakcyjnej, lub

- jest to dopuszczone przez państwo członkowskie.
Hamowanie elektryczne może odbywać się jeśli:

- Jeśli instalacje elektroenergetyczne (podstacje) są do tego przystosowane, oddawanie energii elektrycznej wytwarzanej podczas hamowania jest dopuszczalne, ale nie może powodować przekroczenia wartości granicznych napięcia określonych w normie EN 50163:2004.

- Wszystkie pojazdy szynowe powinny być wyposażone w możliwość odłączania hamulców i sygnalizację stanu hamulców.

- Oprócz tego, pociągi o prędkości maksymalnej większej niż $200 \mathrm{~km} / \mathrm{h}$ należy wyposażyć w układ diagnostyki awarii układu hamulcowego.

Dla hamulców elektromagnetycznych, które stykają się z szyną, stosuje się wymóg mówiący iż nie mogą być one stosowane przy prędkościach większych niż $280 \mathrm{~km} / \mathrm{h}$. Przy ocenie skuteczności hamowania awaryjnego na wszystkich liniach dopuszcza się uwzględnienie w hamowaniu udziału hamulców elektromagnetycznych niezależnych od przyczepności koła do szyny, jako środków zapewniających odpowiednią skuteczność hamowana.

Dla pociągów wyposażonych w hamulce wiroprądowe TSI stawia wymagania, które również wpływają na energochłonność.

Jak wyszczególniono w TSI „Infrastruktura” dla kolei dużych prędkości, wyd. 2006, zastosowanie tego typu hamulca, działającego niezależnie od przyczepności, na liniach (które mają zostać wybudowane, zmodernizowanych lub łączących) transeuropejskiej sieci kolei dużych prędkości jest dozwolone na następujących warunkach:

- Do hamowania awaryjnego na wszystkich liniach oprócz niektórych określonych linii łączących wymienionych w rejestrze infrastruktury.

- Do pełnego lub normalnego hamowania zasadniczego na odcinkach linii, gdzie zezwala na to zarządca infrastruktury. W tym przypadku warunki ich stosowania powinny być zamieszczone $\mathrm{w}$ rejestrze infrastruktury.

Pociagi wyposażone w tego typu hamulce muszą spełniać następujące wymagania techniczne:

- Hamulce niezależne od przyczepności kół do szyn są dopuszczone do stosowania od 
- prędkości maksymalnej do $50 \mathrm{~km} / \mathrm{h}$. (Vmax $\geq \mathrm{V} \geq 50 \mathrm{~km} / \mathrm{h})$

- Maksymalne średnie opóźnienie musi być mniejsze od 2,5 m/s2 (wartość ta, związana $\mathrm{z}$ wzdłużną wytrzymałością toru, musi zostać spełniona przy zastosowaniu wszystkich hamulców).

- W najmniej korzystnym przypadku, tj. dla wielu trakcyjnych pociagów zespołowych połączonych $\mathrm{w}$ trakcji wielokrotnej w pociąg o największej dopuszczalnej długości, największa wzdłużna siła hamowania wywierana na tor przez hamulec wiroprądowy nie może przekraczać:

- $105 \mathrm{kN}$ dla hamowania $\mathrm{z}$ siłą niższą niż $2 / 3$ pełnego hamowania zasadniczego

- Wartości zmiennych liniowo od $105 \mathrm{kN}$ do $180 \mathrm{kN}$ dla hamowania $\mathrm{z}$ siłą od $2 / 3$ do pełnego hamowania zasadniczego

- $180 \mathrm{kN}$ dla pełnego hamowania zasadniczego

- $360 \mathrm{kN}$ podczas hamowania awaryjnego

Te wymagania przytoczone za TSI mają wpływ na energochłonność. Ich wielkość jest uzależniona w zależności od konkretnego pojazdu i jego wyposażenia. Dodatkowo na energochłonność mają wpływ wymagania stawiane hamulcom $w$ różnych sytuacjach takich jak: zabezpieczenie unieruchomionego pociagu, skuteczność hamowania na torach o dużym nachyleniu oraz wymagania dla celów ratowniczych.

Kolejnymi wymaganiami stawianymi pojazdom szynowym wpływającymi na energochłonność są te, które związane są z informacjami dla pasażerów oraz łączności z pasażerami. Jak podkreśla TSI pociagi muszą być wyposażone w minimum środki łączności głosowej, które mają służyć do:

- komunikacji między personelem pociagu $\mathrm{z}$ pasażerami,

- komunikacji personelu pociagu miedzy sobą i kontrolą naziemną,

- komunikacji wewnętrznej pomiędzy członkami pociagu i kontroli naziemnej $\mathrm{w}$ szczególności między maszynistą i personelem znajdującym się $\mathrm{w}$ obszarach zajmowanych przez pasażerów.

Ważnym wymaganiem jest to, że urządzenia te muszą pozostawać w stanie gotowości przez co najmniej trzy godziny niezależnie od głównego źródła zasilania. Zachowana musi być również zasada, że łączność musi być zaprojektowana w taki sposób aby w razie uszkodzenia jednego z elementów zachować ciągłość pracy co najmniej połowy głośników które są rozmieszczone w całym pociągu. Do kontaktowania się pasażerów z personelem powinien być założony alarm.

Komunikacja z pasażerami musi być również zapewniona poprzez umieszczenie urządzeń dla sygnalizacji niebezpieczeństwa. Należy w nie wyposażyć wszystkie pomieszczenia dostępne przez pasażera, za wyjątkiem przedsionków, przejść międzywagonowych i toalet. Uruchomienie alarmu powinno zapoczątkować działania, które również mają wpływ na energochłonność. TSI opisuje takie sytuacje:

- zapoczątkować hamowanie,

- spowodować wyzwolenie optycznego (błyskająca lub świecąca lampka) i dźwiękowego

(brzęczyk/klakson albo komunikat głosowy) alarmu w kabinie maszynisty,

- spowodować wysłanie wiadomości (sygnał dźwiękowy lub optyczny albo komunikat drogą radiową przez radiotelefon lub telefon komórkowy) przez maszynistę lub automatyczny system do personelu pociagu pracującego wśród pasażerów.

- przekazać potwierdzenie, rozpoznawalne przez osobę, która włącza sygnał (sygnał dźwiękowy w pojeździe, włączenie hamulców itp.)

Należy również zwrócić uwage, że pociagi muszą być wyposażone $\mathrm{w}$ instalację do sygnalizacji pożaru taką, który wykryje jego powstanie we wczesnym stadium.

Niezbędnym elementem wyposażenia każdego pociągu wpływającym na energochłonność jest jego oświetlenie zewnętrzne. W przypadku świateł TSI precyzyjnie je definiuje aby uniknąc wątpliwości $\mathrm{W}$ stosowanej nomenklaturze

- Reflektor przedni - białe światło na przednim końcu pociagu, przewidziane do zapewnienia świetlnego ostrzeżenia o zbliżającym się pociągu oraz do oświetlania znaków przy torze,

- Lampa czołowa - białe światło na przednim końcu pociagu przewidziane do sygnalizowania obecności pociągu. 
- Lampa tylna - czerwone światło na tylnym końcu pociagu przewidziane do sygnalizowania obecności pociagu.

- Lampy kombinowane

- Lampy kombinowane (np. lampy wielofunkcyjne) powinny być dozwolone tylko wtedy, gdy spełniają wymagania dla lamp jednofunkcyjnych.

W tabeli 1 zaprezentowano wymagania dla świateł zewnętrznych.

Dla końca pociagu przewidziano wymagania przedstawione w tabeli 2

Wymagania stawiane światłom są zbieżne $\mathrm{z}$ wymaganiami przepisów obowiązujących dla kolei dużych prędkości. Konieczność stosowania przepisów pociaga więc za sobą odpowiednie zapotrzebowanie na energię dla pojazdów poruszających się po torach. Oświetlenie mające na celu zachowanie bezpieczeństwa jest tego istotną częścią. TSI stawia wymagania dotyczące również oświetlenia wnętrza pojazdu w momencie, gdy nastąpi awaria dotyczące czasów działania i natężenia światła. W celu zapewnienia ochrony i bezpieczeństwa na pokładzie pociagu $\mathrm{w}$ sytuacji awaryjnej należy wyposażyć pociagi $w$ system oświetlenia awaryjnego. System ten musi zapewniać natężenie oświetlenia w obszarach przeznaczonych dla pasażerów i obsługi, i spełniać następujące wymagania:

- minimalny czas działania wynosi trzy godziny od chwili utraty głównego zasilania,

- natężenie światła na poziomie podłogi wynosi co najmniej 5 luksów.

W celu zapewnienia komfortu prowadzącemu pojazd wymagana jest wentylacja kabiny maszynisty. Stosowane urządzenia muszą zapewnić $30 \mathrm{~m}^{3} /$ godz. świerzego powietrza. Maszynista musi mieć możliwość odbierania sygnałów o niebezpieczeństwie. Muszą więc być zastosowane systemy diagnostyczne, które pozwolą na czas wykryć usterkę. Do

Tabela 1

Wymagania dla światel

\begin{tabular}{|c|c|c|}
\hline \multicolumn{3}{|c|}{ Światłość lamp głównych } \\
\hline & Lampa główna przyciemniona & Lampa przednia $\mathrm{z}$ pełna moca \\
\hline Światłość w osi lampy (cd) & $12000-16000$ & $>10000$ \\
\hline $\begin{array}{l}\text { Światłość (cd) przy każdym } \\
\text { kącie w zakresie } 5^{0} \text { od osi po } \\
\text { każdej stronie osi w } \\
\text { płaszczyźnie poziomej }\end{array}$ & $>3000$ & $>10000$ \\
\hline \multicolumn{3}{|c|}{ Światłość lamp czołowych } \\
\hline & $\begin{array}{c}\text { Przyciemniona dolna lampa } \\
\text { czołowa }\end{array}$ & $\begin{array}{c}\text { Dolna lampa czołowa z pełną } \\
\text { mocą }\end{array}$ \\
\hline Światłość w osi lampy (cd) & Minimum 1000 & $300-700$ \\
\hline $\begin{array}{l}\text { Światłość (cd) przy każdym } \\
\text { kącie pod kątem } 45^{0} \text { od osi po } \\
\text { każdej stronie osi w } \\
\text { płaszczyźnie poziomej }\end{array}$ & \multicolumn{2}{|c|}{$20-40$} \\
\hline \multicolumn{3}{|c|}{ Światłość górnych lamp czołowych } \\
\hline & $\begin{array}{c}\text { Przyciemniona dolna lampa } \\
\text { czołowa }\end{array}$ & $\begin{array}{c}\text { Przyciemniona dolna lampa } \\
\text { czołowa }\end{array}$ \\
\hline Światłość w osi lampy (cd) & Minimum 50 & $150-350$ \\
\hline
\end{tabular}

Tabela 2

\section{Wymagania dla świateł końca pociągu}

\begin{tabular}{|l|c|}
\hline & Lampa końca pociągu \\
\hline Natężenie światła (cd) na osi lampy $15-40$ & $15-40$ \\
\hline $\begin{array}{l}\text { Natężenie światła (cd) pod kątem } 7,5^{\circ} \text { od osi po } \\
\text { każdej stronie w płaszczyźnie poziomej. Minimum } \\
10\end{array}$ & Minimum 10 \\
\hline $\begin{array}{l}\text { Natężenie światła (cd) pod kątem } 2,5^{\circ} \text { od osi po } \\
\text { każdej stronie w płaszczyźnie pionowej }\end{array}$ & Minimum 10 \\
\hline
\end{tabular}


obowiązkowych systemów diagnostycznych w który musi być wyposażony pojazd należą:

- Działanie drzwi,

- Wykrywanie niestabilności,

- Pokładowe monitorowanie stanu łożysk osi,

- Włączanie alarmu dla pasażerów,

- Układ hamulcowy,

- Wykrywanie wykolejenia,

- Wykrywanie pożaru,

- Awaria urządzenia do kontroli czujności maszynisty,

- Informacje podawane przez podsystem „Sterowanie.

Informacje te ( których większość została omówiona) podnoszą bezpieczeństwo, ale jednocześnie mają wpływ na energochłonność.

Wymagania stawiane koleją dużych, w myśl dyrektywy 2008/57/WE, prędkości są w dużej mierze zbieżne $\mathrm{z}$ wymaganiami stawianymi koleją konwencjonalnym.

\section{Wymagania TSI dla kolei konwencjonalnych}

Podobnie jak dla pociagów dużej prędkości pierwszym elementem wpływającym na energochłonność jest system nagłośnienia i komunikacji z pasażerami. Wymagania stawiane tym elementom są podobne jak dla kolei dużych prędkości i mają podobny wpływ na energochłonność. Podobnie drzwi i okna i szyby. Różnica dla obliczanego bilansu energetycznego pojazdów dużej prędkości i konwencjonalnych może wynikać z dopuszczenia do eksploatacji pojazdów z oknami, które mogą być otwierane przez pasażerów i nie mogą być zablokowane przez pasażerów. Projektując tabor w którym takie rozwiązania mogą mieć zastosowanie należy mieć na uwadze zwiększoną możliwość wymiany powietrza, a w związku z tym zwiększenie zapotrzebowania na energię.

Nieco inne wymagania postawiono oświetleniu zewnętrznemu i sygnałom dźwiękowym. W przypadku wymagań stawianych tym elementom należy brać pod uwagę. Wymagania norm europejskich EN 15153-1 [8] i EN 15153-2 [9]. Jak łatwo zauważyć są to wymagania dla pociagów dużych prędkości. TSI przywołuje je precyzyjnie konkretne punkty tych norm. Wymagania odpowiadają wymagania odpowiadają wymaganiom dla kolei dużych prędkości.
TSI określa również moc maksymalną i prąd maksymalny który może być pobierany $\mathrm{z}$ sieci trakcyjnej. Pojazdom elektrycznym stawia się następujące wymagania:

- Elektryczne pojazdy kolejowe, o mocy wyższej niż $2 \mathrm{MW}$ (w tym zadeklarowany skład stały i predefiniowany) muszą być wyposażone w funkcję ograniczania prądu, zgodnie $\mathrm{z}$ wymaganiem określonym norma EN 50388.

- Elektryczne pojazdy kolejowe muszą być wyposażone w samoczynną regulację prądu w czasie nienormalnych warunków eksploatacji w zakresie napięcia zgodnie z wymaganiem określonym normą EN 50388.

Wymagania w zakresie kabin maszynisty dla kolei konwencjonalnych dotyczących oświetlenia, szyb sygnalizacji uszkodzeń są tożsame $\mathrm{z}$ wymaganiami odnoszącymi się do kolei dużych prędkości. Należy zauważyć, że TSI dla kolei konwencjonalnych powstało później niż dla kolei dużych prędkości i w nieco zmienionych realiach prawnych co może powodować nieznaczne różnice $\mathrm{w}$ stawianych wymaganiach.

\section{Podsumowanie}

Europa dąży do tego, aby pociagi mogły się przemieszczać swobodnie przemieszczać miedzy krajami. Nakłada to na operatorów obowiązek stosowania wymagań dla pociagów poruszających się po sieci interoperacyjnej. Docelowym założeniem jest, aby wszystkie linie stały się interoperacyjne. TSI dla kolei dużych prędkości powstało jako pierwsze i w związku z tym w większym zakresie niż TSI dla kolei konwencjonalnych posiada wymagania bezpośrednie dla pojazdów. TSI dla kolei konwencjonalnych w większym zakresie odwołuje się do norm europejskich, o czym świadczy przykład świateł przywołanej w niniejszym artykule. Wzmagania te mogą również ulegać zmianie wraz z rozwojem kolei i ze zmieniającymi się przepisami i normami. Faktem jest jednak to, że TSI stanowią obowiązujące prawo, które może nieść ze sobą wiele korzyści. Zmiany będą mogły przyczynić się do dynamicznego rozwoju kolei. Najważniejszą jednak zmianą będzie jednak możliwość podróżowania pasażerów i przewóz towa- 
rów bez ograniczeń, a obecnie wymuszany jest rozbiciem i niejednorodnością wymagań, które zależą od legislacji i systemów obowiązujących w poszczególnych krajach.

Wymagania które przedstawiono w artykule sa wybranymi zagadnieniami, które poruszają TSI dla kolei dużych prędkości i kolei konwencjonalnej. Pokazują one jednak, że projektując pojazd i chcąc nieć możliwość kształtowania energochłonności należy każdorazowo brać pod uwagę TSI i stawiane tam wymagania.

\section{Literatura:}

1. Traktat z Lizbony zmieniajacy traktat o Unii Europejskiej i Traktat ustanawiajacy wspólnotę Europejska,

2. Dyrektywa Rady 96/48/WE z dnia 23 lipca 1996 r. w sprawie interoperacyjności transeuropejskiego systemu kolei dużych prędkości,

3. Dyrektywa 2001/16/WE Parlamentu Europejskiego $i$ Rady z dnia 19 marca 2001 r. w sprawie interoperacyjności transeuropejskiego systemu kolei konwencjonalnych,
4. Dyrektywa Parlamentu Europejskiego $i$ Rady 2008/57/WE z dnia 17 czerwca 2008r. w sprawie interoperacyjności systemu kolei we Wspólnocie,

5. Dyrektywa Komisji 2011/18/UE z dnia 1 marca 2011r. zmieniajaca załaczniki II, V i VI do dyrektywy Parlamentu Europejskiego $i$ Rady 200857/WE w sprawie interoperacyjności systemu kolei we wspólnocie,

6. Techniczna Specyfikacja Interoperacyjności dotyczaca podsystemu „Tabor” transeuropejskiego systemu kolei dużych prędkości (2008/232/WE),

7. Techniczna Specyfikacja Interoperacyjności dla podsystemu tabor kolejowy - tabor pasażerski" systemu kolei konwencjonalnych (2011/291/UE),

8. EN 15153-1; Kolejnictwo - Ostrzegawcze urzqdzenia zewnętrzne sygnalizacji optycznej $i$ dźwiękowej pociagów dużej prędkości -- Część 1: Sygnalizacja świetlna czoła i końca pociagu; Lipiec 2007 ,

9. EN 15153-2; Kolejnictwo - Ostrzegawcze urzqdzenia zewnętrzne sygnalizacji optycznej $i$ dźwiękowej pociagów dużej prędkości -- Część 1: Dźwiękowe sygnały ostrzegacze; czerwiec 2007.

10. EN 50388; Zastosowania kolejowe. System zasilania i tabor. Warunki techniczne koordynacji pomiędzy systemem zasilania (podstacja) $i$ taborem $w$ celu osiagnięcia interoperacyjności. 